\title{
Wetland eco-engineering: measuring and modeling feedbacks of oxidation processes between plants and clay-rich material
}

\author{
Rémon Saaltink $^{1}$, Stefan C. Dekker ${ }^{1}$, Jasper Griffioen ${ }^{1,2}$, and Martin J. Wassen ${ }^{1}$ \\ ${ }^{1}$ Department of Environmental Sciences, Copernicus Institute of Sustainable Development, Utrecht University, \\ Utrecht 3508 TC, the Netherlands \\ ${ }^{2}$ TNO Geological Survey of the Netherlands, Princetonlaan 6, 3584 CB Utrecht, the Netherlands
}

Correspondence to: Rémon Saaltink (r.m.saaltink@uu.nl)

Received: 30 March 2016 - Published in Biogeosciences Discuss.: 25 April 2016

Revised: 23 August 2016 - Accepted: 25 August 2016 - Published: 7 September 2016

\begin{abstract}
Interest is growing in using soft sediment as a foundation in eco-engineering projects. Wetland construction in the Dutch lake Markermeer is an example: here, dredging some of the clay-rich lake-bed sediment and using it to construct wetland will soon begin. Natural processes will be utilized during and after construction to accelerate ecosystem development. Knowing that plants can eco-engineer their environment via positive or negative biogeochemical plantsoil feedbacks, we conducted a 6-month greenhouse experiment to identify the key biogeochemical processes in the mud when Phragmites australis is used as an eco-engineering species. We applied inverse biogeochemical modeling to link observed changes in pore water composition to biogeochemical processes. Two months after transplantation we observed reduced plant growth and shriveling and yellowing of foliage. The $\mathrm{N}$ : $\mathrm{P}$ ratios of the plant tissue were low, and these were affected not by hampered uptake of $\mathrm{N}$ but by enhanced uptake of P. Subsequent analyses revealed high Fe concentrations in the leaves and roots. Sulfate concentrations rose drastically in our experiment due to pyrite oxidation; as reduction of sulfate will decouple Fe-P in reducing conditions, we argue that plant-induced iron toxicity hampered plant growth, forming a negative feedback loop, while simultaneously there was a positive feedback loop, as iron toxicity promotes $\mathrm{P}$ mobilization as a result of reduced conditions through root death, thereby stimulating plant growth and regeneration. Given these two feedback mechanisms, we propose the use of Fe-tolerant species rather than species that thrive in $\mathrm{N}$-limited conditions. The results presented in this study demonstrate the importance of studying the biogeochemical properties of the situated sediment and the feed-
\end{abstract}

back mechanisms between plant and soil prior to finalizing the design of the eco-engineering project.

\section{Introduction}

Nowadays, natural processes are being used across the world to achieve fast ecosystem development while at the same time providing opportunities for developing hydraulic infrastructure, a concept called Building with Nature $(\mathrm{BwN})(\mathrm{Tem}-$ merman et al., 2013). Though mostly focused on water safety and coastal protection (e.g., Borsje et al., 2011), BwN can also be applied to the management of fine sediments. A relevant application could be to use soft sediments as material for building freshwater wetlands. Here, vegetation can be used as an eco-engineer (Jones et al., 1994) to modify the environment (Lambers et al., 2009). When fine sediments are used for the construction of wetlands, however, the use of ecoengineers is anticipated to pose challenges in relation to crest stability, consolidation and soil formation.

In the Netherlands, a soft, clay-rich lake-bed sediment is causing serious turbidity problems in the Markermeer (an artificial lake of $691 \mathrm{~km}^{2}$ ): primary productivity is impeded and biodiversity in the lake is declining (Vijverberg et al., 2011; Noordhuis et al., 2014). Because the lake is shallow, windinduced waves frequently induce high bed shear stress, which causes sediment to be resuspended (Vijverberg et al., 2011). To improve the ecological conditions in the lake, plans are underway to dredge some of the soft, clay-rich sediment and use it to construct approximately 10000 ha of wetlands. 
Plants produce root exudates, which influence soil formation by enhancing microbiological activity (Holtkamp et al., 2011), biological weathering and nutrient cycling (Taylor et al., 2009; Bradford et al., 2013). An example is the ability of plant roots to mobilize $\mathrm{P}$ by ligand exchange and dissolution of Fe-bound $\mathrm{P}(\mathrm{Fe}-\mathrm{P})$ by citrate and oxalate excretion (Gerke et al., 2000). Plant roots may also enhance consolidation processes in substrate by increasing horizontal and vertical drainage (O’Kelly, 2006).

However, both negative and positive plant-soil feedbacks exist, in which the physical and chemical properties of the soil affect plant development and vice versa (Ehrenfeld et al., 2005). Therefore, when looking at soil formation, it is important to study the signs and strengths of these plant-soil feedback mechanisms. For example, nutrient conditions codetermine the type of plant community that develops (e.g., Olde Venterink, 2011), which in turn influences the nutrient conditions in the soil itself (Onipchenko et al., 2001). As feedback mechanisms differ between plant species (Ehrenfeld et al., 2005), it is essential to determine which eco-engineer is most appropriate for accelerating ecosystem development in these sediments.

De Lucas Pardo (2014) found that the Markermeer mud deposits had a high water content (20-60\% of fresh weight) and were largely anoxic, with oxygen present only in the top $2 \mathrm{~mm}$. Therefore, when such mud is taken from the lake and spread out in contact with the air, biogeochemical plant-soil processes related to oxidation and drying of the top soil are expected to play a significant role. Two types of clay-rich deposits are the intended sediment for the wetland. Their composition is the product of a combination of historical and present-day factors. Prior to 1932, the year in which the dam cutting off the Zuider Zee from the North Sea was completed, this was a marine environment into which several rivers discharged, including a branch of the River Rhine (the River IJssel). Hence, a near-shore marine deposit underlies the present-day soft, clay-rich sediment. This soft, clay-rich layer is produced by bioturbation and physical weathering and continuously resuspends as a result of wave action (Van Kessel et al., 2008; De Lucas Pardo et al., 2013). This layer accumulated after 1976, when northward sediment transport was blocked by a second dam that separated Markermeer from IJsselmeer, thus allowing suspended matter to resettle on top of the marine deposit. We can therefore distinguish two layers: an upper disturbed mud layer prone to bioturbation and erosion and a relatively undisturbed layer below.

We set up an experiment to monitor the chemical composition of pore water to identify the biogeochemical plant-soil feedback processes that occur when oxidation, drying and modification by plants alter the biogeochemical conditions of these two sediment types, thus in turn affecting vegetation development. Our study has two subsidiary aims: to ascertain how Phragmites australis eco-engineers its environment by expediting biogeochemical processes in the deposits and to simulate the geochemical differences between disturbed mud and undisturbed clay deposits and relate these to the processes identified from the pore water by using PHREEQC (Parkhurst and Apello, 2013) for inverse modeling. In addition, we altered the grain size of the disturbed mud deposit by adding inert sand to see how grain size distribution impacts pore water chemistry.

Changes in biogeochemical processes that are related to oxidation are expected to play a major role as $P$. australis is known for its high radial oxygen loss (Brix et al., 1996; Dickopp et al., 2011; Smith and Luna, 2013). Oxidation of the sediment will decrease the concentration of phytotoxins typically found in waterlogged soils, such as iron, and therefore will have a positive effect on plant development. This will be more pronounced in undisturbed mud, which is largely anoxic, than in disturbed mud, of which the top layer is already oxidized and where bioturbation modified the sediment. The type of biogeochemical processes altered will depend on the intrinsic properties of the different sediment types, which will be examined in this study.

\section{Material and methods}

\subsection{Setup}

A greenhouse experiment was conducted for 6 months at the test facility of Utrecht University. A basin of $4 \mathrm{~m}^{2}(2 \times 2 \mathrm{~m})$ was filled with artificial rainwater and was refreshed every 2 weeks. At regular intervals, the chemistry of the water was checked to ensure that the water composition remained stable during the experiment. The artificial rainwater was made by adding $15 \mu \mathrm{mol} \mathrm{NH} \mathrm{NH}_{4}\left(\mathrm{SO}_{4}\right), 50 \mu \mathrm{mol} \mathrm{NaNO} \mathrm{N}_{3}$ and $30 \mu \mathrm{mol}$ $\mathrm{NaCl}$ to osmosis water. These values reflect the average rainwater composition in the Netherlands for the period 20122013 (LMRe, 2014).

The sediments used include the soft, clay-rich layer $\left(\mathrm{Mud}_{\mathrm{soft}}\right)$ and the underlying, consolidated, Zuider Zee deposit (Clay). In principle, both sediments have the same origin and were collected in the same area. We also included a third sediment type $\left(\mathrm{Mud}_{\text {sand }}\right)$, as it is expected that $\mathrm{Mud}_{\text {soft }}$ will be too soft for constructing wetlands: a $1: 1$ mixture was made by mixing mud with Dorsilit ${ }^{\circledR}$ crystal silica sand (ca. $99 \% \mathrm{SiO}_{2}$ ) which had been autoclaved for $1 \mathrm{~h}$ at $120^{\circ} \mathrm{C}$ prior to mixing. The sand grains of this material are $0.3-$ $0.8 \mathrm{~mm}$ in diameter, with D50 being $0.57 \mathrm{~mm}$. The $\mathrm{Mud}_{\text {soft }}$ and Clay sediments were collected by mechanical dredging in the southern part of the lake and were stored in airtight containers at $4{ }^{\circ} \mathrm{C}$ prior to the start of the experiment.

Plastic pots (diameter $10 \mathrm{~cm}$, depth $18 \mathrm{~cm}$ ) with a perforated base were filled to within $1 \mathrm{~cm}$ from the top with one of the three sediment types used $(t=0)$. In each pot, two soil moisture samplers (Rhizon Flex-5 cm; Rhizosphere, Wageningen, the Netherlands) were installed horizontally at depths of 1 and $11 \mathrm{~cm}$ below the sediment surface (these depths are hereafter referred to as $D_{1}$ and $D_{11}$ ), their tips 
reaching $5 \mathrm{~cm}$ from the pot wall. The pots stood in rows in the basin. The water level was maintained at $9 \mathrm{~cm}$ so that the sediment at $D_{11}$ remained saturated, while the sediment at $D_{1}$ could oxidize and dry. Each sediment type had 13 replicates.

Reed seedlings (Phragmites australis) had been grown in nutrient-poor peat and when 35-40 days old (experimental time $t=22$ days), a single reed seedling was planted per pot in eight of the replicates, leaving five replicates unplanted. Any other seedlings that germinated spontaneously in the pots were removed immediately.

\subsection{Chemical analysis}

Soil moisture at $D_{1}$ and $D_{11}$ was collected from the moisture samplers on days $0,3,10,22,36,64,92,134$ and 174 from five of the pots per condition. The samples from the five replicates were pooled and chemically analyzed. Chloride, $\mathrm{NH}_{4}, \mathrm{NO}_{2}, \mathrm{NO}_{3}$ and $\mathrm{SO}_{4}$ were determined using ion chromatography (IC); Ca, Fe, K, Mg, Na, P, Si and Sr were determined with inductively coupled plasma optical emission spectrometry (ICP-OES), $\mathrm{pH}$ was determined by an ionspecific electrode, and alkalinity was measured by a classic titration method.

Sediment samples were collected for each sediment type at $t=0$ and were freeze-dried and stored anoxically prior to geochemical analysis. The major elements were determined using ICP-OES following an aqua regia destruction. Total S content was measured on an elemental CS analyzer and the mineralogical composition was determined with $\mathrm{X}$ ray diffraction (XRD). A sequential extraction method based on Ruttenberg (1992) was applied to characterize solid P speciation. The method involves five steps (Table 1), the first four of which were carried out anoxically. Loss on ignition (LOI) was determined by slowly heating to $1000^{\circ} \mathrm{C}$. LOI was also used as a proxy for organic matter content and total carbonates by calculating the weight loss between 105 and $550{ }^{\circ} \mathrm{C}$ for organic matter and the weight loss between 550 and $1000^{\circ} \mathrm{C}$ for total carbonates (Howard, 1965). The cation exchange capacity (CEC) of the sediments was calculated from the organic matter content and the amounts and types of clay minerals present (Bauer and Velde, 2014).

Fifty seedlings of $P$. australis randomly chosen from the seedlings grown for the experiment were used to determine the initial tissue contents of $\mathrm{Fe}, \mathrm{K}, \mathrm{P}$ and $\mathrm{N}$. Their roots, shoots and leaves were separated and air-dried. The air-dried material was then ground and analyzed with total reflection X-ray fluorescence (TXRF) to determine tissue contents of $\mathrm{Fe}, \mathrm{K}$ and P. Nitrogen content was determined on an elemental $\mathrm{CN}$ analyzer. At the end of the experiment $(t=174)$, the plants in the pots were harvested and subjected to the same procedure to determine the tissue contents of Fe, K, P and N.

\subsection{Modeling of biogeochemical processes}

To identify important biogeochemical processes during the incubation experiments, we modeled with PHREEQC (Parkhurst and Apello, 2013). PHREEQC modeling is frequently used in geochemical research focusing on issues of water quality: examples include investigating mineral weathering in a mountain river (Lecomte et al., 2005), deducing geochemical processes in groundwater (Belkhiri et al., 2010) and investigating the interaction between two aquifers (Carucci et al., 2012). Here, we applied it to identify biogeochemical plant-soil processes during the oxidation and natural drying out of the soil.

The model approach is based on mass-balance equations of preselected mineral phases (reactants). The mineral phases can either precipitate (leave the solution) or dissolve (enter the solution), and these are expressed in mole transfers. As we only know the dynamics in concentrations of the pore water, we applied inverse modeling, in which all possible combinations of the mass-balance equations are accepted within a range of measured pore water concentrations $\pm 4 \%$. We can simulate infiltration or evaporation rates from the pore water. Since in freshwater mud deposits, the dissolution or precipitation of salts (e.g., $\mathrm{NaCl}$ ) is negligible and can be ignored, the change in pore water $\mathrm{Cl}$ concentration was used to calculate the amount of water evaporated or infiltrated.

To enable the model to attribute some of the chemical changes to cation exchange processes, we included an assemblage of exchangers (X): $\mathrm{Ca} X_{2}, \mathrm{Fe} X_{2}, \mathrm{~K} X, \operatorname{Mg} X_{2}, \mathrm{Na} X$ and $\mathrm{NH}_{4} X$. The sum of this assemblage was defined as CEC calculated from the sediment composition. CEC is important, since it can buffer some of the biogeochemical processes in sediments by adsorption or desorption of cations.

We identified three time frames in our models: (1) oxidation and natural drying out of the soil before the seedlings were transplanted into the pots $(t=0-22$ days); (2) initial stage of plant growth ( $t=22-64$ days); and 3$)$ the stage at which roots started to influence pore water chemistry $(t=$ 64-176 days). These time frames were identified by analyzing the chemical data that were collected. When concentrations at $D_{11}$ in the planted condition started to deviate from the unplanted condition, this was seen as a sign that plant roots started to influence pore water chemistry.

Inverse modeling was applied for all combinations (sediment type, plant/no plant and depth) for each time frame. For every combination, several valid simulations were found, due to small differences in the amount of mole transfers attributed to the mineral phases. Here we present the plausible simulation with the least amount of mole transfers for each combination.

\subsection{Statistical analysis}

Statistical analysis was carried out using the programs $\mathrm{R}$ and SPSS. Differences in sediment, pore water and plant tis- 
Table 1. List of steps used in the extraction procedure of phosphorus (based on Ruttenberg, 1992).

\begin{tabular}{|c|c|c|c|}
\hline Step & & Extractant & Separated $\mathrm{P}$ fraction \\
\hline I & & $1 \mathrm{M} \mathrm{MgCl}_{2}, 30 \mathrm{~min}$ & Exchangeable or loosely sorbed $\mathrm{P}$ \\
\hline II & $\begin{array}{l}\mathrm{A} \\
\mathrm{B}\end{array}$ & $\begin{array}{l}\text { Citrate-dithionite-bicarbonate (CDB), } 8 \mathrm{~h} \\
1 \mathrm{M} \mathrm{MgCl}_{2}, 30 \mathrm{~min}\end{array}$ & Easily reducible or reactive ferric Fe-P \\
\hline III & $\begin{array}{l}\mathrm{A} \\
\mathrm{B}\end{array}$ & $\begin{array}{l}\mathrm{Na} \text { acetate buffer }(\mathrm{pH} 4), 6 \mathrm{~h} \\
1 \mathrm{M} \mathrm{MgCl}_{2}, 30 \mathrm{~min}\end{array}$ & Amorphous apatite and carbonate $\mathrm{P}$ \\
\hline IV & & $1 \mathrm{M} \mathrm{HCl}, 24 \mathrm{~h}$ & Crystalline apatite and other inorganic $P$ \\
\hline $\mathrm{V}$ & & Ash at $550^{\circ} \mathrm{C}, 2 \mathrm{~h} ; 1 \mathrm{M} \mathrm{HCl}, 24 \mathrm{~h}$ & Organic $\mathrm{P}$ \\
\hline
\end{tabular}

sue concentrations between sediment treatments were determined using one-way ANOVA with a Tukey's honestly significant difference (HSD) post hoc test. No statistics could be applied to the mineralogical sediment composition (XRD analysis) due to the absence of replicates.

\section{Results and discussion}

First, the three sediment types will be compared in terms of certain geochemical and mineralogical elements. Next, the composition of the pore water will be introduced and will be linked to biogeochemical processes by presenting and discussing the PHREEQC model simulations. Then, the plant response is presented and discussed in terms of biomass and plant tissue chemistry. Lastly, the implications for ecoengineering will be discussed.

\subsection{A brief comparison between sediment types}

Table 2 shows the geochemical composition of the disturbed Mud $_{\text {soft }}$ and Mud ${ }_{\text {sand }}$ and undisturbed Clay sediments used in this study. The differences between Mud ${ }_{\text {soft }}$ and Mud ${ }_{\text {sand }}$ are solely attributable to the presence of inert Dorsilit ${ }^{\circledR}$.

The total sediment concentrations of $\mathrm{Al}, \mathrm{Fe}, \mathrm{Mg}, \mathrm{Mn}, \mathrm{Na}$, $\mathrm{P}$ and $\mathrm{Zn}$ were significantly higher in Clay than in $\mathrm{Mud}_{\text {soft }}$ $(p<0.05)$. The quartz content was also higher in Clay, which suggests that there were more reactive minerals in this type of sediment.

Sequential $P$ extraction revealed that the significant difference in total $\mathrm{P}$ consists of a significantly lower content of Fe-P in Mud $_{\text {soft }}$ than in Clay $\left(279 \mathrm{mg} \mathrm{kg}^{-1}\right.$ vs. $772 \mathrm{mg} \mathrm{kg}^{-1}$; $p<0.01)$. The presence of $\mathrm{Fe}-\mathrm{P}$ in the anoxic Clay sediment was unexpected, as in anoxic conditions Fe prefers to bind with $\mathrm{S}$ to form $\mathrm{FeS}_{2}$. However, after exhaustion of $\mathrm{S}$, precipitation of $\mathrm{Fe}$ (II) phosphates may occur (Jilbert and Slomp, 2013). Another possibility is that the reduction of crystalline $\mathrm{Fe}$ (III) is not complete in the anoxic sediment because kinetic processes are slow (Canavan et al., 2007). This is likely the case in Markermeer, given our strict anoxic procedures for storage and analysis of the samples. The exchangeable (or loosely sorbed) P was low in Mud ${ }_{\text {soft }}$ and Clay, indicating that only a small part of the total P found in the sediments was readily available for uptake. The other three P pools were fairly similar and did not differ significantly between the two types of sediment ( $p=0.42$ for Ca-bound $\mathrm{P} ; p=0.11$ for detrital $\mathrm{P}$; and $p=0.94$ for organic $\mathrm{P})$.

The mineralogical analysis (XRD) showed not only that the quartz content was lower in Mud $_{\text {soft }}$ than in Clay (37\% vs. $48 \%$ ) but that the amounts of calcite and pyrite did not differ between the two types of sediment ( $9 \%$ calcite and $0.6 \%$ pyrite). The amount of phyllosilicates (sum of illite, smectite, kaolinite and chlorite) was higher in Mud $_{\text {soft }}$ than in Clay: $43 \%$ vs. $30 \%$. This must also have caused the CEC to be higher in $\mathrm{Mud}_{\text {soft }}$, as the organic matter content did not differ much between the two $\left(7.2 \%\right.$ in $\mathrm{Mud}_{\text {soft }}$ and $6.8 \%$ in Clay).

\subsection{Pore water composition}

Figure 1 presents time series for the pore water concentrations of the three macronutrients $\mathrm{N}, \mathrm{P}$ and $\mathrm{K}$. The initial decrease in $\mathrm{NH}_{4}$ and increase in $\mathrm{NO}_{x}$ at a depth $D_{1}$ for the planted conditions was most likely caused by nitrification as a result of oxidation (Fig. 1a-f). At the end of the experiment, almost all dissolved inorganic nitrogen had been removed from the pore water in the pots with plants, whereas in the pots without plants, the $\mathrm{NH}_{4}$ concentrations remained substantial. Furthermore, a high peak in $\mathrm{NO}_{x}$ was observed in Clay sediments at day 10 of the experiment. At a depth $D_{11}$, no large changes were found in general for $\mathrm{NH}_{4}$ and $\mathrm{NO}_{x}$.

A sharp decline in soluble $\mathrm{P}$ was visible at $D_{1}$ for all three sediments, probably because $\mathrm{P}$ precipitated with $\mathrm{Fe}$ (III) when oxygen penetrated the top layer (Fig. 1g-i). However, in Clay this decline was preceded by an increase in P. After several weeks, a thin moss layer started to develop on top of the $\mathrm{Mud}_{\text {soft }}$ sediment, which probably prevented oxygen from penetrating and thereby increased the $\mathrm{P}$ concentrations (Fig. 1g). Similar developments were observed for Mud ${ }_{\text {sand }}$ although here the moss layer developed much later. In Clay, no moss grew throughout the experiment.

Concentrations of $\mathrm{K}$ were higher than concentrations of $\mathrm{N}$ and $\mathrm{P}$ and increased in the first few weeks (Fig. 1j-1). No difference was found between pots at $D_{11}$ with or with- 
Table 2. Geochemical and mineralogical composition of the sediment types used in this study. Significant differences between Mud soft $_{\text {and }}$ Clay are indicated by $*(p<0.05)$.

\begin{tabular}{|c|c|c|c|c|c|c|c|c|}
\hline & \multirow[b]{2}{*}{ Unit } & \multirow{2}{*}{$\begin{array}{l}n \text { per } \\
\text { type }\end{array}$} & \multirow{2}{*}{$\begin{array}{l}\text { Clay } \\
\text { Mean }\end{array}$} & \multirow[b]{2}{*}{ SD } & \multirow{2}{*}{$\begin{array}{r}\text { Mud }_{\text {soft }} \\
\text { Mean }\end{array}$} & \multicolumn{3}{|c|}{ Mud $_{\text {sand }}$} \\
\hline & & & & & & SD & Mean & SD \\
\hline \multicolumn{9}{|l|}{ Aqua regia/CS } \\
\hline $\mathrm{Al}^{*}$ & $\mathrm{mg} \mathrm{kg}^{-1}$ & 15 & 21989 & 4512 & 16593 & 3130 & 6394 & 2439 \\
\hline $\mathrm{Ca}$ & $\mathrm{mg} \mathrm{kg}^{-1}$ & 15 & 48031 & 3032 & 45635 & 6020 & 18877 & 3572 \\
\hline $\mathrm{Fe}^{*}$ & $\mathrm{mg} \mathrm{kg}^{-1}$ & 15 & 27766 & 3764 & 20745 & 2987 & 7804 & 2281 \\
\hline $\mathrm{K}$ & $\mathrm{mg} \mathrm{kg}^{-1}$ & 15 & 5371 & 1262 & 4102 & 641 & 1723 & 742 \\
\hline $\mathrm{Mg}^{*}$ & $\mathrm{mg} \mathrm{kg}^{-1}$ & 15 & 8041 & 1017 & 6636 & 906 & 2531 & 558 \\
\hline $\mathrm{Mn}^{*}$ & $\mathrm{mg} \mathrm{kg}^{-1}$ & 15 & 710 & 166 & 577 & 160 & 238 & 62 \\
\hline $\mathrm{Na}^{*}$ & $\mathrm{mg} \mathrm{kg}^{-1}$ & 15 & 992 & 379 & 526 & 158 & 219 & 64 \\
\hline $\mathrm{P}^{*}$ & $\mathrm{mg} \mathrm{kg}^{-1}$ & 15 & 1186 & 217 & 649 & 169 & 259 & 56 \\
\hline $\mathrm{S}$ & $\mathrm{mg} \mathrm{kg}^{-1}$ & 15 & 5727 & 710 & 5586 & 698 & 3001 & 846 \\
\hline $\mathrm{Sr}$ & $\mathrm{mg} \mathrm{kg}^{-1}$ & 15 & 148 & 21 & 135 & 26 & 62 & 14 \\
\hline $\mathrm{Ti}$ & $\mathrm{mg} \mathrm{kg}^{-1}$ & 15 & 312 & 74 & 312 & 77 & 125 & 44 \\
\hline $\mathrm{Zn}^{*}$ & $\mathrm{mg} \mathrm{kg}^{-1}$ & 15 & 159 & 58 & 110 & 29 & 43 & 18 \\
\hline \multicolumn{9}{|l|}{ Seq. P extraction } \\
\hline Exchangeable P & $\mathrm{mg} \mathrm{kg}^{-1}$ & 15 & 14.3 & 6.81 & 11.9 & 3.50 & 5.9 & 1.79 \\
\hline Fe-bound $\mathrm{P}^{*}$ & $\mathrm{mg} \mathrm{kg}^{-1}$ & 15 & 772 & 263 & 279 & 61.7 & 94.5 & 29.0 \\
\hline Ca-bound P & $\mathrm{mg} \mathrm{kg}^{-1}$ & 15 & 146 & 43.3 & 121 & 30.9 & 36.8 & 13.1 \\
\hline Detrital P & $\mathrm{mg} \mathrm{kg}^{-1}$ & 15 & 147 & 16.5 & 169 & 14.1 & 51.5 & 10.9 \\
\hline Organic $\mathrm{P}$ & $\mathrm{mg} \mathrm{kg}^{-1}$ & 15 & 99.6 & 20.0 & 117 & 25.1 & 47.7 & 8.38 \\
\hline \multicolumn{9}{|l|}{ XRD } \\
\hline Quartz & $\%$ & 1 & 48 & & 37 & & n.a. & \\
\hline Calcite & $\%$ & 1 & 9 & & 9 & & n.a. & \\
\hline Pyrite & $\%$ & 1 & 0.6 & & 0.6 & & n.a. & \\
\hline Illite & $\%$ & 1 & 15 & & 21 & & n.a. & \\
\hline Smectite & $\%$ & 1 & 11 & & 14 & & n.a. & \\
\hline Kaolinite & $\%$ & 1 & 3 & & 5 & & n.a. & \\
\hline Chlorite & $\%$ & 1 & 2 & & 3 & & n.a. & \\
\hline \multicolumn{9}{|l|}{ Other } \\
\hline Organic matter & $\%$ & 5 & 6.7 & 0.6 & 7.2 & 0.6 & 2.8 & 0.4 \\
\hline CEC (calculated) & $\mathrm{meq} / 100 \mathrm{~g}$ & & 30.0 & & 37.2 & & 12.4 & \\
\hline
\end{tabular}

out plants. However, $\mathrm{K}$ was significantly higher at $D_{1}$ in the planted pots with Mud $_{\text {sand }}(p<0.05)$.

Although it may be important to study measured concentrations of nutrients in pore water in order to understand plant functioning, deriving biogeochemical processes from measured data is problematic as changes in pore water can be caused by multiple processes such as drying, dilution, dissolution and precipitation. Figure 2 reveals that the drying of soils at $D_{1}$ was probably an important factor because we observed an initial increase in $\mathrm{Cl}$ that indicated that $\mathrm{Cl}$ could not dissolve in the three sediments used (e.g., halite dissolution). Drying will have influenced other variables as well, such as sulfate (Fig. 2d-f). Comparing the patterns of $\mathrm{Cl}$ and $\mathrm{SO}_{4}$ suggests that the change in $\mathrm{SO}_{4}$ concentrations at $D_{1}$ should be partly attributed to drying out of soils and partly either to dissolution (e.g., pyrite oxidation) or to precipitation (e.g., gypsum formation). This highlights the need to use geochemical reaction models like PHREEQC to inversely derive biogeochemical processes from measured data.

\subsection{Pore water processes (PHREEQC model simulations)}

The main pore water processes modeled by PHREEQC are presented in Table 3. For clarity, only major reactants are included in this Table. Supplement Tables S1 and S2 present mole transfers for all reactants used, as well as the number of valid simulations per combination found. 

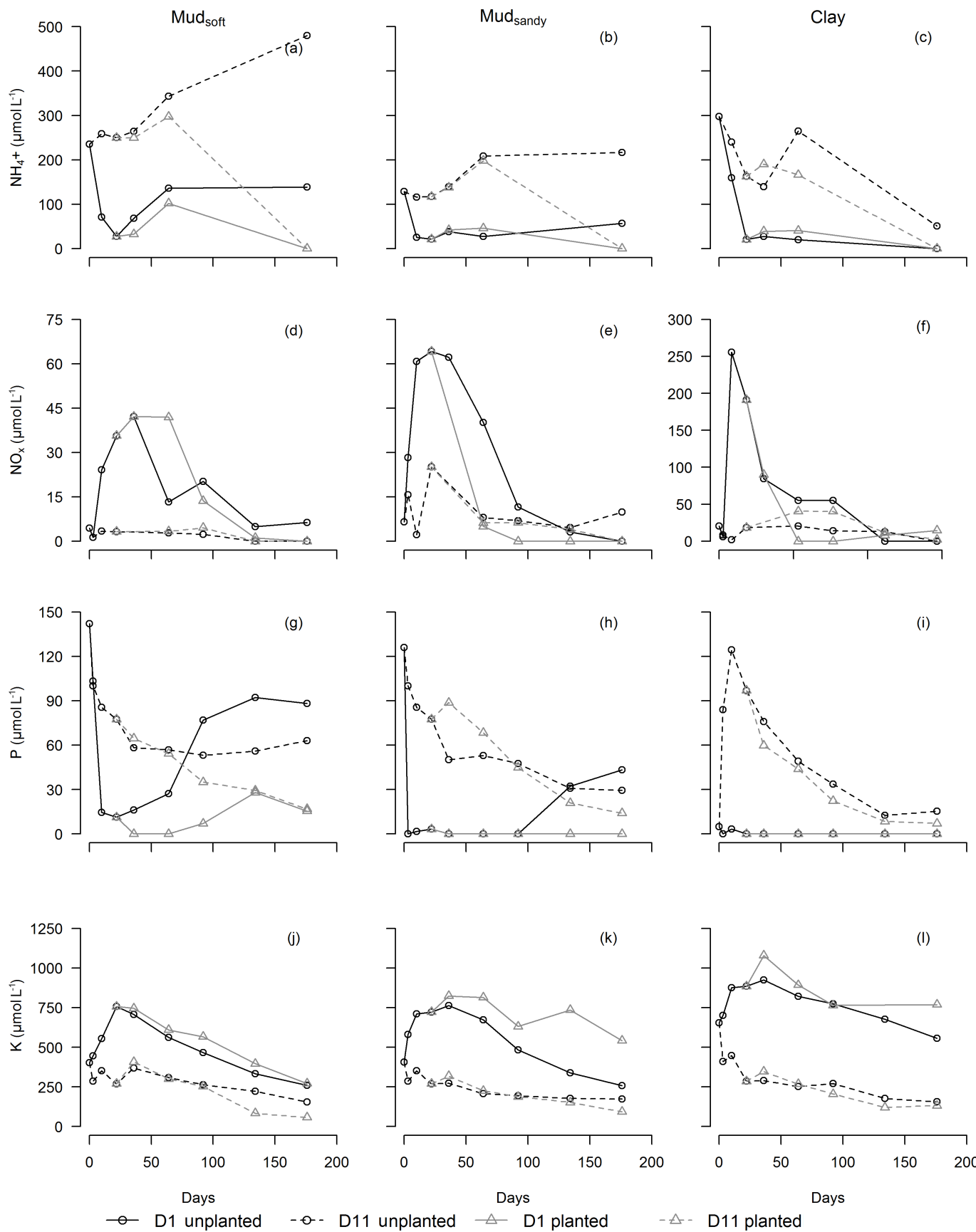

Figure 1. Time series of $\mathrm{NH}_{4}(\mathbf{a}-\mathbf{c}), \mathrm{NO}_{x}(\mathbf{d}-\mathbf{f}), \mathrm{P}(\mathbf{g}-\mathbf{i})$ and $\mathrm{K}(\mathbf{j}-\mathbf{l})$ concentrations. Each column represents one sediment type: Mud $\mathrm{soft}_{\mathrm{t}}(\mathbf{a}$, $\mathbf{d}, \mathbf{g}, \mathbf{j}), \operatorname{Mud}_{\text {sand }}(\mathbf{b}, \mathbf{e}, \mathbf{h}, \mathbf{k})$ and Clay $(\mathbf{c}, \mathbf{f}, \mathbf{i}, \mathbf{l})$. The variable and the scale of the $x$ axis are the same for each row, except for the scale in $(\mathbf{f})$.

\subsubsection{Phase 1: oxidation and drying $(t=0-22$ days $)$}

As discussed in Sect. 3.2, initial drying of soils occurred at $D_{1}$ immediately after exposure to air. In the model, this is illustrated by high evaporation rates expressed as $\mathrm{H}_{2} \mathrm{O}$ loss (2300-3400 $\mathrm{mmol} \mathrm{L}^{-1}$ day $^{-1}$; Table 3). The model accounts for this loss by adjusting the solution fractions before calculating other mole transfers.
Exposure to air also leads to oxidation, more so at $D_{1}$ than at $D_{11}$ (Table 3 ). The increase in measured sulfate is partly explained as pyrite oxidation $\left(109-270 \mu \mathrm{mol} \mathrm{L}^{-1}\right.$ day $^{-1}$ for $D_{1}$ and $20.1-36.2 \mu \mathrm{mol} \mathrm{L}^{-1}$ day $^{-1}$ for $D_{11}$, respectively). Oxidation of pyrite also produces iron oxyhydroxides and protons, which in turn promotes the dissolution of calcite. The overall reactions are

$$
\mathrm{FeS}_{2}+3.75 \mathrm{O}_{2}+3.5 \mathrm{H}_{2} \mathrm{O} \rightarrow \mathrm{Fe}(\mathrm{OH})_{3}+2 \mathrm{SO}_{4}^{2-}+4 \mathrm{H}^{+},
$$



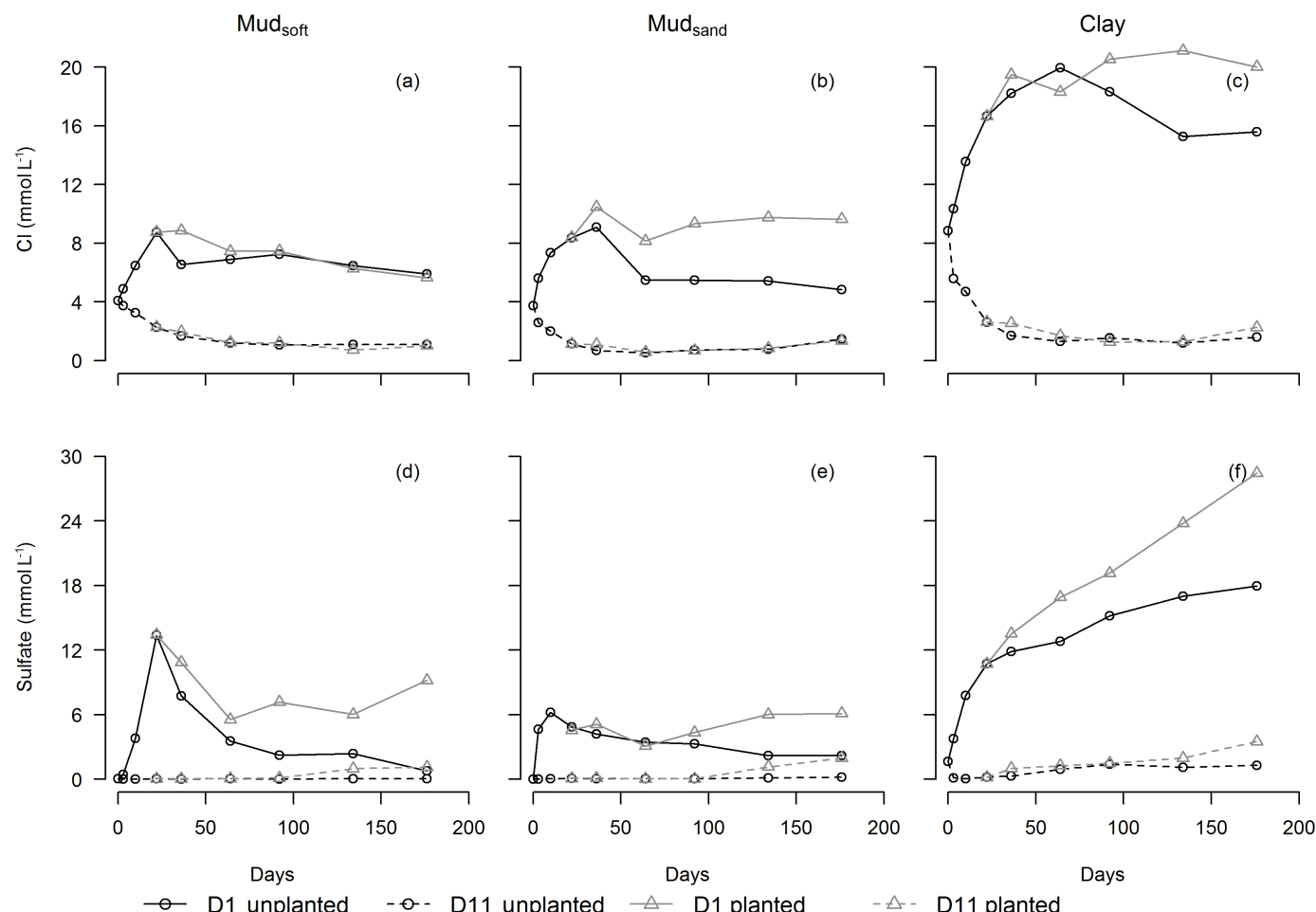

Figure 2. Time series of $\mathrm{Cl}(\mathbf{a}-\mathbf{c})$ and sulfate $(\mathbf{d}-\mathbf{f})$ concentrations. Each column represents one sediment type: $\operatorname{Mud}_{\text {soft }}(\mathbf{a}, \mathbf{d}), \mathrm{Mud}_{\mathrm{sand}}(\mathbf{b}, \mathbf{e})$ and Clay (c, f). The variable and the scale of the $x$ axis are the same for each row.

Table 3. Main pore water processes expressed in mole transfers $\left(\mu \mathrm{mol} \mathrm{L} \mathrm{L}^{-1} \mathrm{~d}^{-1}\right)$ as modeled by PHREEQC with pore water data retrieved at 1 and $11 \mathrm{~cm}$ below sediment surface ( $D_{1}$ and $D_{11}$, respectively). Positive values indicate dissolution; negative values indicate precipitation. Cation exchange capacity (CEC) is the sum of $\mathrm{Ca}, \mathrm{Fe}, \mathrm{K}, \mathrm{Mg}, \mathrm{Na}$ and $\mathrm{NH}_{4}$.

\begin{tabular}{|c|c|c|c|c|c|c|c|c|c|c|c|c|c|c|c|c|}
\hline \multirow{5}{*}{$\begin{array}{l}\text { Phase } \\
\begin{array}{l}\text { 1. Oxidation } \\
t=0-22 \text { days }\end{array}\end{array}$} & & & \multicolumn{2}{|c|}{ Calcite } & \multicolumn{2}{|c|}{ Gypsum } & \multicolumn{2}{|c|}{$\mathrm{Fe}(\mathrm{OH})_{3}$} & \multicolumn{2}{|c|}{ Pyrite } & \multicolumn{2}{|c|}{$\Sigma \mathrm{CEC}$} & \multicolumn{2}{|c|}{$\mathrm{H}_{2} \mathrm{O}\left(\times 10^{3}\right)$} & \multicolumn{2}{|c|}{$\mathrm{O}_{2}$} \\
\hline & \multicolumn{2}{|c|}{ Condition } & $D_{1}$ & $D_{11}$ & $D_{1}$ & $D_{11}$ & $D_{1}$ & $D_{11}$ & $D_{1}$ & $D_{11}$ & $D_{1}$ & $D_{11}$ & $D_{1}$ & $D_{11}$ & $D_{1}$ & $D_{11}$ \\
\hline & $\mathrm{Mud}_{\text {soft }}$ & No plant & 267 & 111 & 0.00 & -72.5 & -277 & 0.00 & 270 & 36.2 & -31.3 & 20.2 & -3364 & 0.00 & 1009 & 119 \\
\hline & Mud $_{\text {sand }}$ & No plant & 0.00 & 59.6 & 0.00 & -40.7 & -116 & 0.00 & 109 & 21.7 & -4.99 & 7.92 & -2591 & 0.00 & 432 & 69.5 \\
\hline & Clay & No plant & 120 & 55.2 & 0.00 & -53.4 & -160 & 0.00 & 159 & 20.1 & -91.4 & 14.0 & -2364 & 0.00 & 659 & 61.9 \\
\hline \multirow{6}{*}{$\begin{array}{l}\text { 2. Initial root } \\
\text { development } \\
t=22-64 \text { days }\end{array}$} & \multirow[t]{2}{*}{$\operatorname{Mud}_{\text {soft }}$} & No plant & 27.1 & 0.00 & -236 & 0.00 & 0.95 & -0.24 & 0.00 & 0.00 & -23.1 & 1.43 & 0.00 & 0.00 & 2.62 & 0.00 \\
\hline & & Plant & 48.8 & 19.8 & -208 & -3.81 & -10.0 & -6.19 & 9.76 & 0.00 & -7.63 & 1.43 & 0.00 & 0.00 & 45.5 & 0.00 \\
\hline & \multirow[t]{2}{*}{ Mud $_{\text {sand }}$} & No plant & 39.3 & 71.7 & 0.00 & 0.00 & 0.00 & -41.2 & 0.21 & 0.00 & 1.90 & 1.46 & 380 & 0.00 & 0.00 & 0.00 \\
\hline & & Plant & 7.10 & 83.8 & -83.4 & 0.00 & 0.00 & -51.2 & 3.58 & 0.00 & 5.40 & 3.40 & -996 & 0.00 & 0.00 & 0.00 \\
\hline & \multirow[t]{2}{*}{ Clay } & No plant & 0.00 & 27.1 & -32.1 & 0.00 & -21.4 & -25.0 & 21.2 & 0.00 & 0.01 & -0.23 & -286 & 0.00 & 41.9 & 0.00 \\
\hline & & Plant & 36.9 & 16.2 & 0.00 & 0.00 & -14.3 & 0.00 & 64.3 & 11.9 & 28.4 & 4.53 & -6.67 & 0.00 & 186 & 40.5 \\
\hline \multirow{6}{*}{$\begin{array}{l}\text { 3. Root influence } \\
t=64-176 \text { days }\end{array}$} & \multirow[t]{2}{*}{ Mud $_{\text {soft }}$} & No plant & 0.00 & -3.21 & -19.2 & 0.00 & -1.34 & -0.80 & 0.00 & 0.00 & -1.07 & -1.43 & 56.3 & 0.00 & 0.00 & 0.00 \\
\hline & & Plant & 25.8 & 0.00 & 0.00 & 0.00 & -4.20 & 0.00 & 23.8 & 4.11 & 7.88 & -4.65 & 49.1 & 0.00 & 83.6 & 13.6 \\
\hline & \multirow[t]{2}{*}{ Mud $_{\text {sand }}$} & No plant & 8.13 & 0.00 & -7.59 & 0.00 & -10.6 & -1.34 & 0.00 & 0.00 & -1.78 & 1.42 & 74.1 & 0.00 & 0.00 & 0.00 \\
\hline & & Plant & 0.00 & 0.00 & -14.8 & 0.00 & -13.3 & -23.2 & 13.8 & 7.95 & 0.12 & -10.6 & -357 & -652 & 44.7 & 32.6 \\
\hline & \multirow[t]{2}{*}{ Clay } & No plant & 0.00 & 11.5 & 0.00 & 0.00 & 0.00 & -13.8 & 33.3 & 0.00 & 23.9 & 0.36 & 134 & 0.00 & 113 & 0.00 \\
\hline & & Plant & 115 & 18.7 & 0.00 & 0.00 & -58.5 & -8.48 & 58.3 & 8.57 & 45.4 & -5.73 & 0.00 & -98.2 & 215 & 28.4 \\
\hline
\end{tabular}

followed by calcite dissolution

$\mathrm{CaCO}_{3}+\mathrm{H}^{+} \rightarrow \mathrm{Ca}^{2+}+\mathrm{HCO}_{3}^{-}$.

The mole transfers for pyrite and calcite presented in Table 3 indicate that not enough calcite is dissolved to buffer all $\mathrm{H}^{+}$produced by dissolution of pyrite. Indeed, a drop in $\mathrm{pH}$ was observed at the beginning of the experiment (not shown). However, the mineralogical composition presented in Table 2 shows that the amount of calcite $(9 \% ; 900 \mathrm{mmol})$ far exceeds that of pyrite $(0.6 \% ; 50 \mathrm{mmol})$. These numbers suggest that even if all pyrite were to be oxidized, enough calcite is present to buffer all $\mathrm{H}^{+}$produced $(200 \mathrm{mmol})$. Note that for $\mathrm{Mud}_{\text {sand }}$ these values are lower due to mixing with Dorsilit $^{\circledR}$. 


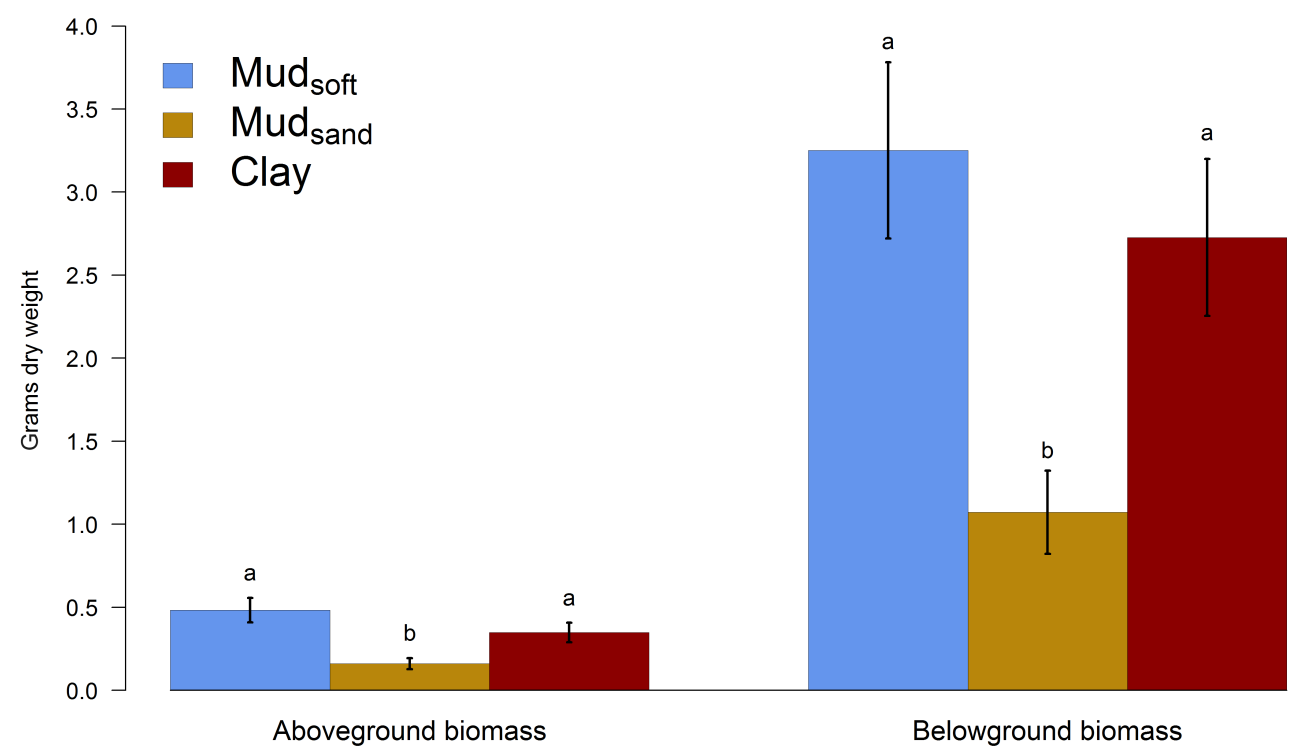

Figure 3. Above- and belowground biomass in grams dry weight, with error bars $(n=5)$. Significant differences between sediment types are indicated by different letters, and nonsignificant differences are indicated by the same letter.

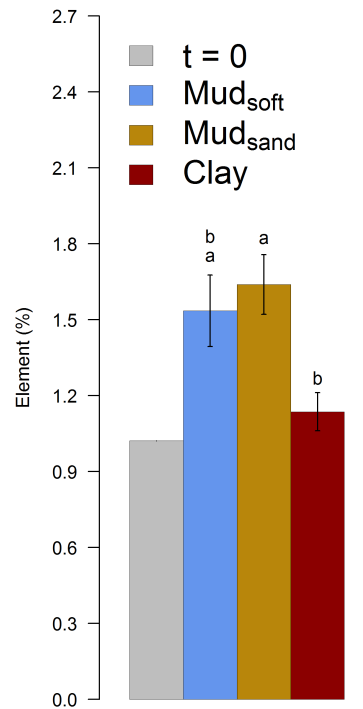

$\mathrm{N}$

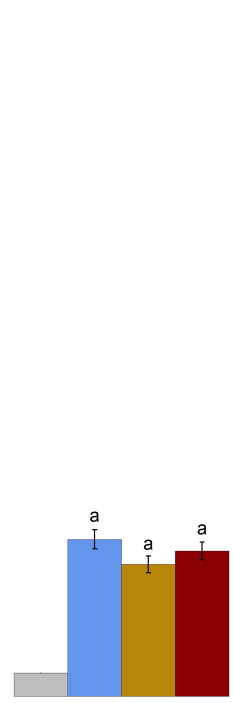

$\mathrm{P}$

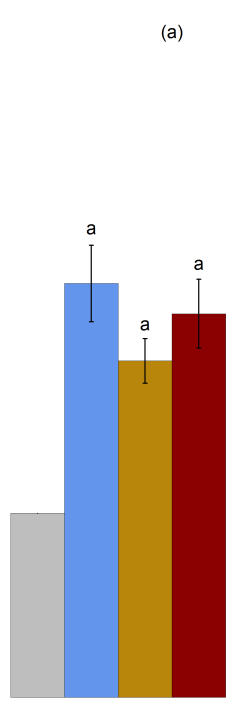

$\mathrm{K}$

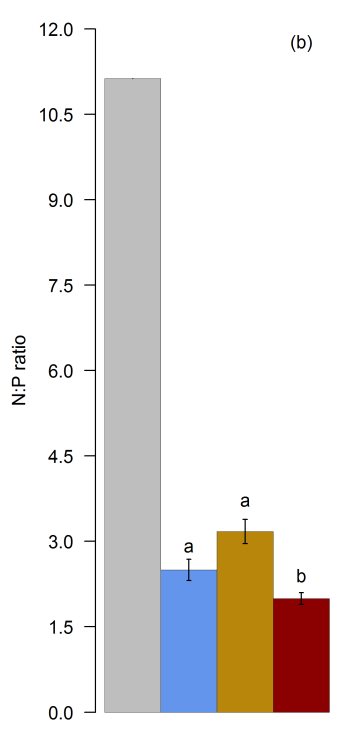

)

Figure 4. $\mathrm{N}, \mathrm{P}$ and $\mathrm{K}$ concentration in root tissue $(t=176)$ in percentage of dry weight (a) as well as the $\mathrm{N}: \mathrm{P}$ ratio (b) with error bars when $n=5$. Significant differences between sediment types are indicated by different letters, and nonsignificant differences are indicated by the same letter.

Some aeration occurred at $D_{11}$. The $\mathrm{O}_{2}$ fluxes ranged between 61 and $119 \mu \mathrm{mol} \mathrm{L}^{-1}$ day $^{-1}$, which resulted in small amounts of pyrite being oxidized $\left(20-36 \mu \mathrm{mol} \mathrm{L}^{-1} \mathrm{day}^{-1}\right)$. However, sulfate concentrations did not rise, as a result of subsequent precipitation with $\mathrm{Ca}$ to form gypsum (53$73 \mu \mathrm{mol} \mathrm{L}^{-1}$ day $^{-1}$ ). Furthermore, the CEC of the sediments buffered some processes in pore water chemistry by net adsorption of cations at $D_{1}$ and net desorption at $D_{11}$.
The processes described above occurred in all three sediments, although oxidation was higher in Mud $_{\text {soft }}$ than in $\mathrm{Mud}_{\text {sand }}$ and Clay, probably because higher evaporation rates in $\mathrm{Mud}_{\text {soft }}$ enhanced oxidation and affected other reactants related to oxidation. 

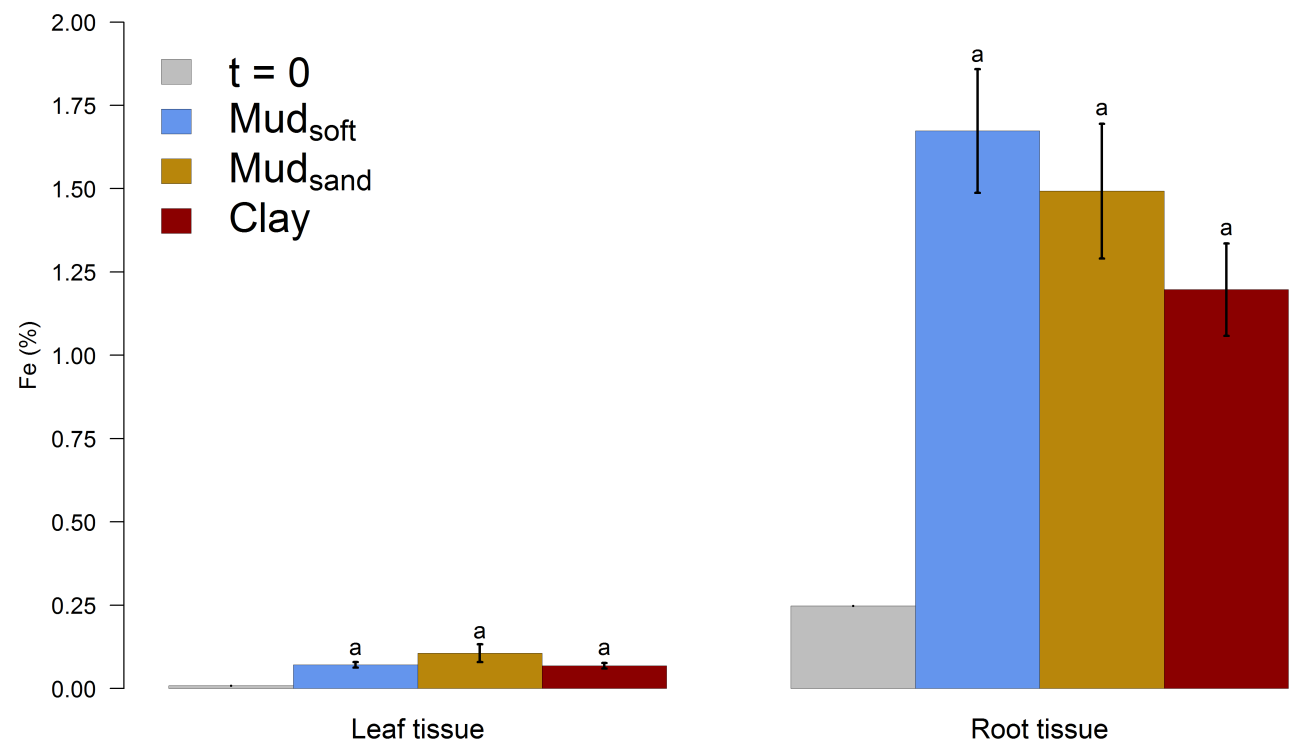

Figure 5. Fe concentration (\% of dry weight) in leaf and root tissue with error bars when $n=5$. Significant differences between sediment types are indicated by different letters, and nonsignificant differences are indicated by the same letter.

\subsubsection{Phase 2: initial stage of plant growth $(t=22-64$ days)}

While the pore water compositions did not show clear differences between unplanted and planted conditions during the initial stage of plant growth, the inverse modeling provided clear evidence for differences at $D_{1}$. However, chemical differences between unplanted and planted conditions for $\operatorname{Mud}_{\text {sand }}$ might simply be attributed to concentration/dilution due to $\mathrm{H}_{2} \mathrm{O}$ loss/gain ( -996 to $380 \mathrm{mmol} \mathrm{L}^{-1}$ day $^{-1}$ ).

Overall, more pyrite was oxidized in the planted conditions, though the rates are much lower than in the first phase $\left(0-64.3 \mu \mathrm{mol} \mathrm{L}^{-1} \mathrm{day}^{-1}\right)$. This observation provides evidence that plants may enhance pyrite oxidation by radial oxygen loss (i.e., root aeration). Ferric oxide production on pyrite surfaces probably impeded further oxidation of pyrite, which is a common phenomenon in carbonate-buffered conditions (Nicholson et al., 1990). Indeed, the total pyrite that had oxidized after 64 days $\left(6.3 \mathrm{mmol}\right.$ for $\mathrm{Mud}_{\text {soft }}, 2.5 \mathrm{mmol}$ for $\mathrm{Mud}_{\mathrm{sand}}$ and $6.2 \mathrm{mmol}$ for Clay, calculated from the rates presented in Table 3 ) corresponds to a small fraction of total pyrite present $(50 \mathrm{mmol})$.

Saturation with gypsum led to precipitation of $\mathrm{SO}_{4}$ and $\mathrm{Ca}$ at $D_{1}$. Table 3 shows that with the exception of $\mathrm{Mud}_{\text {sand }}$, mole transfers were lower for planted conditions; the probable reason is that citric acid production by root tips retarded gypsum precipitation (Prisciandaro et al., 2005). This process was not relevant at $D_{11}$, as here aeration (and subsequent sulfate production) by plant roots was minor (in the case of Clay) or absent (in the case of $\mathrm{Mud}_{\text {soft }}$ and Mud ${ }_{\text {sand }}$ ).

The thin moss layer that started to develop after several weeks in the unplanted condition on top of the Mud soft $_{\text {sedi- }}$ ment slowed down the aeration rate to $2.62 \mu \mathrm{mol} \mathrm{L}^{-1}$ day $^{-1}$ and might be the reason for the moderate increase in $\mathrm{P}$, which probably resulted from $\mathrm{Fe}(\mathrm{OH})_{3}$ dissolution $\left(0.95 \mu \mathrm{mol} \mathrm{L}^{-1} \mathrm{day}^{-1}\right)$ (Fig. 1g, Table 3).

\subsubsection{Phase 3: root influence $(t=64-176$ days $)$}

Phase 3 took place in the autumn, when temperatures were lower and therefore the soils did not dry out; hence, there was a net gain in $\mathrm{H}_{2} \mathrm{O}$. The gain was less in planted conditions, due to the uptake of water by roots.

The fully grown plants continued to influence pore water chemistry at $D_{1}$, but in the unplanted conditions the chemical changes were minor (Table 3 ). Radial oxygen loss continued the oxidation processes described in the previous sections. It should be noted that $P$. australis is known to have higher radial oxygen loss than other wetland species (Brix et al., 1996; Dickopp et al., 2011; Smith and Luna, 2013), so the aeration effect found in this study cannot be assumed to hold for other species.

In contrast to the previous phase, in phase 3 the influence of roots was clearly visible at $D_{11}$ for all three sediments. All planted sediments showed increased aeration and subsequent oxidation of pyrite due to radial oxygen loss, with a notable difference between Mud $_{\text {soft }}$ (lower) and Mud $_{\text {sand }}$ (higher). This is somewhat surprising, as the belowground biomass was significantly higher in Mud $_{\text {soft }}$ (Sect. 3.4). It indicates that increasing the average grain size by adding sand enhanced aeration, even when root biomass production was low. 


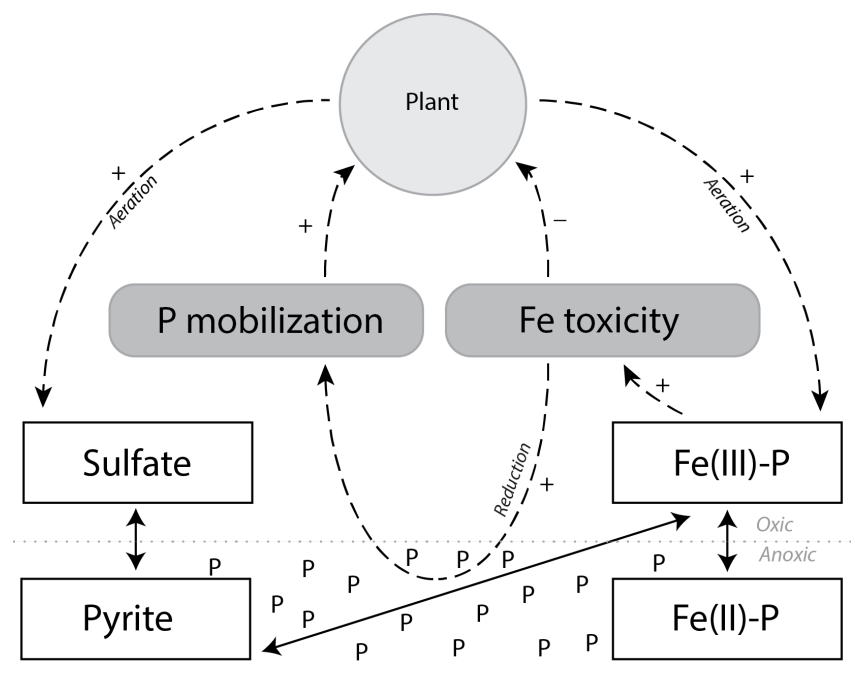

Figure 6. Most important biogeochemical processes and feedbacks identified in this study. + indicates positive feedback; - indicates negative feedback.

\subsection{Plant response}

Above- and belowground biomass was significantly higher in Mud $_{\text {soft }}$ and Clay than in Mud ${ }_{\text {sand }}$ (Fig. 3; $p<0.02$ ). The difference between the two Mud sediments cannot be explained by nutrient concentrations in pore water or light conditions in the greenhouse, as these were the same for the two sediments. As biomass production in $\mathrm{Mud}_{\text {sand }}$ was not limited by chemical or biological properties relative to Mud $_{\text {soft }}$, it seems likely that the reason for the lower biomass production in $\operatorname{Mud}_{\text {sand }}$ is a difference in physical properties. Voorhees et al. (1975) and Bengough and Mullins (1990) showed that so-called mechanical impedance (i.e., the resistance to penetration by the root tip) was higher in loamy sand than in clay, which was attributed to the higher bulk density of the loamy sand. Therefore, increasing the bulk density of Mud $_{\text {soft }}$ by mixing with sand increased the mechanical impedance, and this might explain the lower biomass production we observed in Mud $_{\text {sand }}$.

$P$. australis invested more in its root system than in its shoots and leaves for all sediments (Fig. $3 ; p<0.01$ ). More investment in roots implies a limitation of $\mathrm{N}, \mathrm{P}$ and/or $\mathrm{S}$ (Ericsson, 1995; Shipley and Meziane, 2002). Figures 1a-i and $2 \mathrm{~d}-\mathrm{f}$ show that the $\mathrm{N}$ and $\mathrm{P}$ concentrations were indeed low in the planted conditions but that $\mathrm{SO}_{4}$ was high, which rules out $\mathrm{S}$ limitation. During the experiment, we had observed reduced plant growth and shriveling and yellowing of foliage 2 months after transplantation, which might have been caused by nutrient limitation.

Figure 4 shows the N, P and K contents as well as the N:P ratio for the roots of $P$. australis at the beginning and end of the experiment for the three sediment types. The N, P and $\mathrm{K}$ contents in the roots increased in time, while the $\mathrm{N}: \mathrm{P}$ ratio clearly decreased. The reduction in $\mathrm{N}$ : $\mathrm{P}$ ratio from 11 to $2-3$ suggests $\mathrm{N}$ was the limiting nutrient as an $\mathrm{N}: \mathrm{P}$ ratio of $<14$ in plant tissue is indicative of $\mathrm{N}$ limitation (Koerselman and Meuleman, 1996). However, root $\mathrm{N}$ and $\mathrm{P}$ concentrations of P. australis should typically range between 0.64 and $1.04 \%$ for $\mathrm{N}$ and $0.06-0.13 \%$ for $\mathrm{P}$ (Wang et al., 2015). Figure 4 shows that the root $\mathrm{N}$ and $\mathrm{P}$ concentrations were above these values and that $\mathrm{P}$ was particularly high: they were higher by a factor of 5-10 (N: $1.14-1.63 \%$ and P: 0.52-0.62 \%). Hence, the concentrations of these nutrients in the roots do not indicate that nutrient limitation is a likely cause of the reduced plant growth and shriveling and yellowing of foliage.

We hypothesize that coprecipitation of $\mathrm{P}$ with $\mathrm{Fe}$ on roots enhanced the concentrations of $\mathrm{P}$ in the plant roots (Snowden and Wheeler, 1995; Jørgenson et al., 2012). Snowden and Wheeler (1995) showed that this so-called iron plaque formation enhances the uptake of $\mathrm{Fe}$ and $\mathrm{P}$. This may cause iron toxicity and is probably responsible for the elevated P concentrations in tissue and for the stunted growth and leaf decay we observed in the experiment. Note that the plant roots of $P$. australis initiate this process by oxidizing their environment and thereby enabling ferrous iron to oxidize into P-bearing ferric iron, which precipitates on roots.

The Fe concentration in the leaves and in the roots supports the "Fe-P coprecipitation hypothesis": we measured an approximately 20 -fold increase by comparison with the initial concentration in the seedlings (Fig. 5). Furthermore, ferric oxide, a product of pyrite oxidation, precipitates on root surfaces (Jørgenson et al., 2012), and hence pyrite oxidation in sediments is directly linked to iron toxicity in plants.

Further evidence to support our hypothesis is provided by the results of the sequential phosphorus extraction conducted on the sediments: it revealed that the dominant $P$ pool in the sediments is the Fe-P fraction (Table 2). P coprecipitates with $\mathrm{Fe}$ on roots if it is bound to ferric oxides.

\subsection{Implications for eco-engineering}

Our results strongly point in the direction of iron toxicity as a major bottleneck prohibiting the healthy development of $P$. australis. Since the candidate material for the construction of the Markermeer wetland has high contents of $\mathrm{Fe}$ and $\mathrm{Fe}-\mathrm{P}$, we recommend using Fe-tolerant plant species as test species in the new wetland, rather than species optimized for growing in $\mathrm{N}$-limited conditions.

Concomitantly with iron toxicity, a high Fe-P content in soil will trigger $\mathrm{P}$ mobilization if that soil is rewetted after having dried out and contains high amounts of $\mathrm{SO}_{4}$ (Smolders and Roelofs, 1993; Lucassen et al., 2005). In some cases, this can result in elevated levels of sulfide, thereby promoting S toxicity in plants (Lamers et al., 1998; Van der Welle et al., 2007).

Figure 6 summarizes the important feedbacks and processes we expect play an important role in the clay-rich sediments. Following the feedback loops between plant and soil, we see a negative feedback loop that arises because plant 
roots induce aeration, which promotes iron toxicity, which decreases plant growth and results in plant death. Also, we see a positive feedback loop, as iron toxicity induces reduction processes as a result of root death, which leads to $\mathrm{P}$ mobilization and hence enhances plant growth and regeneration. Negative feedback loops diminish or buffer changes, whereas a positive feedback loop amplifies changes. So, a negative feedback loop normally stabilizes the system, in our case via the toxic effect of iron oxides on plants, but plant growth may increase due to the positive feedback loop via $\mathrm{P}$ mobilization. The relative strengths of these two feedback loops and the sensitivity of species to Fe toxicity determine the ultimate effect on vegetation development in wetlands built from these sediments.

As drying-rewetting cycles are likely to occur in these future wetlands and since the Fe-P concentrations in the situated sediment are high, these feedbacks might be an important factor influencing soil formation and ecosystem development. We therefore recommend studying the ultimate effects of the use of this material on ecosystem development by testing with various plant species and drying-rewetting cycles.

Not all environmental factors that potentially interfere with the processes and feedbacks described in this study could be taken into account with this experimental design (e.g., wave action, wind). Therefore, we recommend carrying out experiments on the wetlands themselves once the crest has stabilized sufficiently.

\section{Conclusions}

The results of this study show that plants expedite biogeochemical processes by oxidizing and modifying their environment, which in turn affects the growth conditions of the plants. In the mud deposits from Markermeer, the key processes influencing pore water chemistry are pyrite oxidation and associated calcite dissolution. The former is especially likely to be important as it is linked to iron toxicity and $\mathrm{P}$ mobilization and thus has the potential to initiate two feedback mechanisms between plant and soil. We found strong indications of a negative feedback loop, where plant-induced iron toxicity is hampering plant growth, and a positive feedback loop, where iron toxicity promotes $\mathrm{P}$ mobilization, enhancing plant growth. The strength of these feedbacks and the balance between them will play an important role in regulating eco-engineering conditions for plants.

We found conclusive evidence that the low $\mathrm{N}: \mathrm{P}$ ratio found in plant tissue was not caused by $\mathrm{N}$ limitation, as the ratio suggests, but probably results from enhanced $\mathrm{P}$ uptake as a result of coprecipitation with $\mathrm{Fe}$ on roots.

The magnitudes of the feedback mechanisms are expected to differ between the sediments used. The soft clay-rich layer has less Fe-P than the underlying clay layer, and therefore $\mathrm{P}$ mobilization is expected to be less in mud. However, when the mud is mixed with sand, the enhanced aeration due to the change in grain size composition results in higher oxidation rates, increasing the impact of the positive feedback mechanisms involving P mobilization and iron toxicity.

To study the effects of iron toxicity and P mobilization in greater detail, we recommend further testing with different plant species and drying-rewetting cycles. This is important because we expect these mechanisms to influence soil formation and ecosystem development in the created wetlands.

\section{Data availability}

A dataset containing all relevant data acquired in this study is archived at DANS (Data Archiving and Networked Systems) and is accessible to all users (Saaltink et al., 2016).

\section{The Supplement related to this article is available online at doi:10.5194/bg-13-4945-2016-supplement.}

Acknowledgements. This study was supported with funding from the Netherlands Organization for Scientific Research (NWO), project no. 850.13.032, and the companies Boskalis and Van Oord. We would also like to thank the Botanical Garden Utrecht for their help, support and advice during the greenhouse experiment. Joy Burrough advised us regarding English usage. Lastly, we would like to thank Ingrid Bauer and an anonymous referee for helpful comments on the manuscript.

Edited by: V. Brovkin

Reviewed by: I. Bauer and one anonymous referee

\section{References}

Bauer, A. and Velde, B. D.: Soils: Retention and Movement of Elements at the Interface, in: Geochemistry at the Earth's Surface: Movement of Chemical Elements, Springer-Verlag Berlin Heidelberg, New York, 2014.

Belkhiri, L., Boudoukha, A., Mouni, L., and Baouz, T.: Application of multivariate statistical methods and inverse geochemical modeling for characterization of groundwater - A case study: Ain Azel plain (Algeria), Geoderma, 159, 390-398, 2010.

Bengough, A. G. and Mullins, C. E.: Mechanical impedance to root growth: a review of experimental techniques and root growth responses, J. Soil Sci., 41, 341-358, 1990.

Borsje, B. W., Van Wesenbeeck, B. K., Dekker, F., Paalvast, P., Bouma, T. J., Van Katwijk, M., and De Vries, M. B.: How ecological engineering can serve in coastal protection, Ecol. Engin., 37, 113-122, 2011.

Bradford, M. A., Keiser, A. D., Davies, C. A., Mersmann, C. A., and Strickland, M. S.: Empirical evidence that soil carbon formation from plant inputs is positively related to microbial growth, Biogeochemistry, 113, 271-281, 2013. 
Brix, H., Borrell, B. K., and Schierup, H. H.: Gas fluxes achieved by in situ convective flow in Phragmites australis, Aquat. Bot., 54, 151-163, 1996.

Canavan, R. W., Van Cappellen, P., Zwolsman J. J. G., Van den Berg, G. A., and Slomp, C. A.: Geochemistry of trace metals in a fresh water sediment: Field results and diagenetic modeling, Sci. Total Environ., 381, 263-279, 2007.

Carucci, V., Petitta, M., and Aravena, R.: Interaction between shallow and deep aquifers in the Tivoli Plain (Central Italy) enhanced by groundwater extraction: A multi-isotope approach and geochemical modeling, Appl. Geochem., 27, 266-280, 2012.

De Lucas Pardo, M. A., Bakker, M., Van Kessel, T., Cozzoli, F., and Winterwerp, J. C.: Erodibility of soft freshwater sediments in Markermeer: the role of bioturbation by meiobenthic fauna, Ocean Dynam., 63, 1137-1150, 2013.

De Lucas Pardo, M. A.: Effect of biota on fine sediment transport processes, A study of lake Markermeer, Ph.D thesis, Delft University, the Netherlands, 211 pp., 2014.

Dickopp, J., Kazda, M., and Cízková, H.: Differences in rhizome aeration of Phragmites australis in a constructed wetland, Ecol. Engin., 37, 1647-1653, 2011.

Ehrenfeld, J. G., Ravit, B., and Elgersma, K.: Feedback in the plantsoil system, Ann. Rev. Environ. Resour., 30, 75-115, 2005.

Ericsson, T.: Growth and shoot:root ratio of seedlings in relation to nutrient availability, Plant Soil, 168, 205-214, 1995.

Gerke, J., Beissner, L., and Römer W.: The quantitative effect of chemical phosphate mobilization by carboxylate anions on $\mathrm{P}$ uptake by a single root, I. The basic concept and determination of soil parameters, J. Plant Nutr. Soil Sc., 163, 207-212, 2000.

Holtkamp, R., Van der Wal, A., Kardol, P., Van Putten, W. H., De Ruiter, P. C., and Dekker, S. C.: Modelling C and N mineralisation in soil food webs during secondary succession on ex-arable land, Soil Biol. Biochem., 43, 251-260, 2011.

Howard, P. J. A.: The Carbon-Organic Matter Factor in Various Soil Types, Oikos, 15, 229-236, 1965.

Jilbert, T. and Slomp C. P.: Iron and manganese shuttles control the formation of authigenic phosphorus minerals in the euxinic basins of the Baltic Sea, Geochim. Cosmochim. Acta, 107, 155169, 2013

Jones, C. G., Lawton, J. H., and Shachak, M.: Organisms as Ecosystem Engineers, Oikos, 69, 373-386, 1994.

Jørgenson, K. D., Lee, P. F., and Kanavillil, N.: Ecological relationships of wild rice, Zizania spp. 11. Electron microscopy study of iron plaques on the roots of northern wild rice (Zizania palustris), Botany, 91, 189-201, 2012.

Koerselman, W. and Meuleman, A. F. M.: The vegetation N : P ratio: a new tool to detect the nature of nutrient limitation, J. Appl. Ecol., 33, 1441-1450, 1996.

Lambers, H., Mougel, C., Jaillard, B., and Hinsinger P.: Plantmicrobe-soil interactions in the rhizosphere: an evolutionary perspective, Plant Soil, 321, 83-115, 2009.

Lamers, L. P. M., Tomassen, H. B. M., and Roelofs J. G. M.: Sulfate-Induced Eutrophication and Phytotoxicity in Freshwater Wetlands, Environ. Sci. Technol., 32, 199-205, 1998.

Lecomte, K. L., Pasquini, A. I., and Depetris, P. J.: Mineral weathering in a Semiarid Mountain River: Its assessment through PHREEQC inverse modeling, Aquat. Geochem., 11, 173-194, 2005.
LMRe (Landelijk Meetnet Regenwater): http://www.lml.rivm.nl/ gevalideerd/, last access: 17 November 2014.

Lucassen, E. C .H. E. T., Smolders, A. J. P., Lamers, L. P. M., and Roelofs, J. G. M.: Water table fluctuations and groundwater supply are important in preventing phosphate-eutrophication in sulphate-rich fens: Consequences for wetland restoration, Plant Soil, 269, 109-115, 2005.

Nicholson, R. V., Gillham, R. W., and Reardon E. J.: Pyrite oxidation in carbonate-buffered solution: 2 . Rate control by oxide coatings, Geochim. Cosmochim. Acta, 54, 395-402, 1990.

Noordhuis, R., Groot, S., Dionisio Pires, M., and Maarse M.: Wetenschappelijk eindadvies ANT-IJsselmeergebied. Vijf jaar studie naar kansen voor het ecosysteem van het IJsselmeer, Markermeer en IJmeer met het oog op de Natura-2000 doelen, Open File Rep. 1207767-000, 98 pp., 2014.

O'Kelly, B. C.: Compression and consolidation anisotropy of some soft soils, Geotechnol. Geol. Engin., 24, 1715-1728, 2006.

Olde Venterink, H.: Does phosphorus limitation promote speciesrich plant communities?, Plant Soil, 345, 1-9, 2011.

Onipchenko, V. G., Makarov, M. I., and Van der Maarel, E.: Influence of alpine plants on soil nutrient concentrations in a monoculture experiment, Folia Geobot., 36, 225-241, 2001.

Parkhurst, D. L. and Appelo, C. A. J.: Description of input and examples for PHREEQC version 3-A computer program for speciation, batch-reaction, one-dimensional transport, and inverse geochemical calculations, US Geol. Surv., Denver, 497 pp., 2013.

Prisciandaro, M., Santucci, A., Lancia, A., and Musmarra, D.: Role of citric acid in delaying gypsum precipitation, Can. J. Chem. Engin., 83, 586-592, 2005.

Ruttenberg, K. C.: Development of a sequential extraction method for different forms of phosphorus in marine sediments, Limnol. Oceanogr., 37, 1460-1482, 1992.

Saaltink, R., Dekker, S. C., Griffioen, J., and Wassen, M. J.: Data from: Wetland eco-engineering: measuring and modeling feedbacks of oxidation processes between plants and clay-rich material, Data Archiving and Networked Services (DANS), http: //dx.doi.org/10.17026/dans-xpq-hz5m, 2016.

Shipley, B. and Meziane D.: The balanced-growth hypothesis and the allometry of leaf and root biomass allocation, Funct. Ecol., 16, 326-331, 2002.

Smith, K. E. and Luna, T. O.: Radial Oxygen Loss in Wetland Plants: Potential Impacts on Remediation of Contaminated Sediments, J. Environ. Engin., 139, 496-501, 2013.

Smolders, A. and Roelofs J. G. M.: Sulphate-mediated iron limitation and eutrophication in aquatic ecosystems, Aquat. Bot., 46, 247-253, 1993.

Snowden, R. E. D. and Wheeler, B. D.: Chemical changes in selected wetland plant species with increasing Fe supply, with specific reference to root precipitates and Fe tolerance, New Phytol., 131, 503-520, 1995.

Taylor, L. L., Leake, J. R., Quirk, J., Hardy, K., Banwart, S. A., and Beerling, D. J.: Biological weathering and the long-term carbon cycle: integrating mycorrhizal evolution and function into the current paradigm, Geobiology, 7, 171-191, 2009.

Temmerman, S., Meire, P., Bouma, T. J., Herman, P. M. J., Ysebaert, T., and De Vriend, H. K.: Ecosystem-based coastal defence in the face of global change, Nature, 504, 79-83, 2013. 
Van der Welle, M. E. W., Smolders, A. J. P., Op den Camp, H. J. P., Roelofs, J. G. M., and Lamers, L. P. M.: Biogeochemical interactions between iron and sulphate in freshwater wetlands and their implications for interspecific competition between aquatic macrophytes, Freshwater Biol., 52, 434-447, 2007.

Van Kessel, T., De Boer, G., and Boderie P.: Calibration suspended sediment model Markermeer, Open File Rep. 4612, 107 pp., 2008.

Vijverberg, T., Winterwerp, J. C., Aarninkhof, S. G. J., and Drost, H.: Fine sediment dynamics in a shallow lake and implication for design of hydraulic works, Ocean Dynam., 61, 187-202, 2011.
Voorhees, W. B., Farrel, D. A., and Larson, W. E.: Soil strength and aeration effects on root elongation, Soil Sci. Soc. Am. J., 39, 948-953, 1975.

Wang, W. Q., Sardans, J., Wang, C., Zeng, C. S., Tong, C., Asensio, D., and Penuelas, J.: Ecological stoichiometry of $\mathrm{C}, \mathrm{N}$, and $\mathrm{P}$ of invasive Phragmites australis and native Cyperus malaccensis species in the Minjiang River tidal estuarine wetlands of China, Plant Ecol., 216, 809-822, 2015. 